\title{
Protonic Conduction in Oxides at Elevated Temperatures and Their Possible Applications
}

\author{
Hiroyasu IWAHARA, * Tetsuo SHIMURA, and Hiroshige MATSUMOTO
}

\begin{abstract}
Center for Integrated Research in Science and Engineering, Nagoya University (Furo-cho, Chikusa-ku, Nagoya 4648603, Japan)
\end{abstract}

Received October 13, 1999 ; Accepted December 27, 1999

\begin{abstract}
Protonic conduction in oxide ceramics under hydrogen-containing atmosphere at elevated temperatures is reviewed with respect to oxide materials, their electrochemical properties, conduction mechanism and possible applications. These oxides are unique in respect of the fact that they have no protons as a host component, but incorporate protons via reactions with the atmosphere. The materials of this class are some perovskite-type oxides and other oxides which contain crystal defects. Defect equilibria for proton formation in these kinds of oxides are discussed citing some experimental results. Possible electrochemical devices using proton conducting ceramics are briefly introduced.
\end{abstract}

Key Words : Protonic Conduction, Perovskite-type Oxides, Electrochemical Hydrogen Pump, Hydrogen Sensor

\section{Introduction}

It is about twenty years since high temperature proton conducting ceramics based on strontium cerates with relatively high conductivity were reported by us. ${ }^{1)}$ Since then, a number of studies on proton conduction in various oxide ceramics have been carried out by many researchers. More than 200 papers have been published concerning the preparation of the ceramics, their crystal structure, the formation of protons in the oxides, the mechanism of protonic conduction and their applications. Most of them are concerned with perovskite-type oxides.

In the present paper, protonic conduction in the oxides especially for perovskite-type ones is briefly summarized and their electrochemical properties, defect chemistry and possible applications are described citing the experiments performed mainly in our laboratory.

\section{Proton Conducting Oxide Ceramics : Materials and Properties}

A typical example of proton conducting oxide of this class is $\mathrm{SrCe}_{0.95} \mathrm{Yb}_{0.05} \mathrm{O}_{3-a}$, a substituted solid solution based on the perovskite-type oxide $\mathrm{SrCeO}_{3}$, in which $5 \%$ of $\mathrm{Ce}$ are replaced by $\mathrm{Yb}$. The ceramic of this material exhibits protonic conduction under hydrogencontaining atmosphere at elevated temperatures. Other perovskite-type oxides based on $\mathrm{SrCeO}_{3}$ or $\mathrm{BaCeO}_{3}$, in which some trivalent cations are partially substituted for cerium, are also protonic conductors under similar condition to the above. ${ }^{1-4)}$ The general formula is written as $\mathrm{SrCe}_{1-x} \mathrm{M}_{x} \mathrm{O}_{3-a}$ or $\mathrm{BaCe}_{1-x} \mathrm{M}_{x} \mathrm{O}_{3-a}$ where $\mathrm{M}$ is some rare earth element, $x$ is less than its upper limit of solid solution formation range (usually less than 0.2 ) and $a$ is the oxygen deficiency per unit formula which depends on the concentration of dopant $M$ and surrounding atmosphere. Their conductivities in hydrogen atmosphere are of the order of $10^{-1} \sim 10^{-3} \mathrm{~S} \mathrm{~cm} \mathrm{~cm}^{-1}$ at $1000 \sim 600^{\circ} \mathrm{C}$ as shown in Fig. 1. The protonic conduction in these oxides was verified by electrochemical experiments as described in Section 3.

After the discovery of $\mathrm{SrCeO}_{3}$-based protonic conductors, $\mathrm{KTaO}_{3}$-based oxides ${ }^{5}$ and $\mathrm{Y}_{2} \mathrm{O}_{3}$ ceramic $^{6)}$ were reported to have protonic conduction at high temperatures, although the conductivities were not as high as those of the cerate-based perovskite-type oxide ceramics. Some doped zirconates based on $\mathrm{CaZrO}_{3}, \mathrm{SrZrO}_{3}$ or $\mathrm{BaZrO}_{3}{ }^{7,8)}$ and scandates based on $\mathrm{LnScO}_{3}(\mathrm{Ln}=\mathrm{La}, \mathrm{Nd}, \mathrm{Sm} \text { or } \mathrm{Gd})^{9}{ }^{9}$ were also confirmed to exhibit the same behavior as the above cerates, although their conductivities were rather low, as shown in Fig. 1.

Among the oxides described above, $\mathrm{BaCeO}_{3}$-based ceramics show the highest conductivity. However, the con-

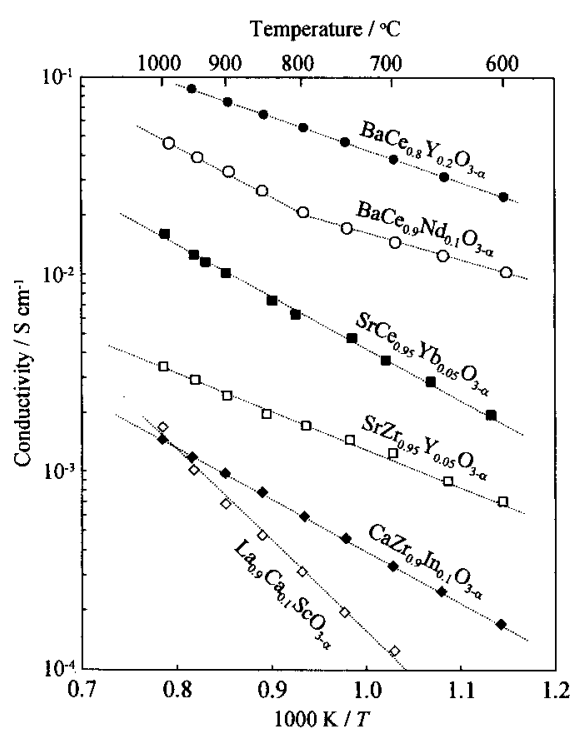

Fig. 1 Conductivities of typical proton conducting perovskitetype oxide ceramics under hydrogen gas atmosphere. 
tribution of oxide-ions to the conduction grows markedly as the temperature is raised. ${ }^{3,10-12)}$ Although the conductivity of $\mathrm{SrCeO}_{3}$-based ceramic is rather low, the transport number of protons is higher than that of $\mathrm{BaCeO}_{3}$ based one. The conductivities of zirconate-based ceramics are lower than those of the cerates, but they are superior with respect to their chemical and mechanical strength.

The cerates dissolve easily in the strong acids. For example, $\mathrm{SrCeO}_{3}$-based ceramics dissolve into concentrated hydrochloric acid liberating chlorine gas. ${ }^{13)}$ However, zirconates hardly react with acid solution and they are stable against carbon dioxide gas, which reacts with cerate ceramics below $800^{\circ} \mathrm{C}$ to form carbonates..$^{14,15}$ )

Several years ago, Nowick et al. have reported a series of new protonic conductors ${ }^{16)}$ in the mixed perovskites of the types $\mathrm{A}_{2}\left(\mathrm{~B}^{\prime} \mathrm{B}^{\prime \prime}\right) \mathrm{O}_{6}$ and $\mathrm{A}_{3}\left(\mathrm{~B}^{\prime} \mathrm{B}^{\prime}{ }_{2}\right) \mathrm{O}_{9}$ in which the $\mathrm{A}$ ions are always charged $2+$ and the $\mathrm{B}^{\prime}$ and $\mathrm{B}^{\prime}$ ions have charges $3+$ and $5+$ in the former case and $2+$ and $5+$ in the latter. Protonic conduction occurs when the composion of cations is slightly shifted from stoichiometric one. As an example, $\mathrm{Ba}_{3}\left(\mathrm{Ca}_{1.18} \mathrm{Nb}_{1.82}\right) \mathrm{O}_{9-a}$ which is derived from $\mathrm{Ba}_{3}\left(\mathrm{CaNb}_{2}\right) \mathrm{O}_{9}$ exhibits a conductivity as high as that of $\mathrm{BaCeO}_{3}$-based ceramics.

Recently some of perovskite-related oxides were also confirmed to exhibit protonic conduction under similar condition as above. Indium- or magnesium-doped $\mathrm{Sr}_{2} \mathrm{TiO}_{4}$ ceramics whose crystal structure belongs to $\mathrm{K}_{2} \mathrm{NiF}_{4}$-type (a kind of layered perovskite-type) show protonic conduction under hydrogen-containing atmosphere at elevated temperatures, although appreciable electronic conduction is accompanied. ${ }^{17,18)} \quad \mathrm{Sr}_{2} \mathrm{TiO}_{4}$ has a two-dimensional perovskite-type layer $\left(\mathrm{SrTiO}_{3}\right)$ sandwiched by a NaCl-type SrO-layer. Similar behavior was observed in $\mathrm{Sr}_{3} \mathrm{Ti}_{2} \mathrm{O}_{7^{-}}$ based ceramics, although the conductivity is low compared to that of $\mathrm{Sr}_{2} \mathrm{TiO}_{4}$-based solid solution. ${ }^{19)} \mathrm{In}_{\mathrm{Sr}_{3} \mathrm{Ti}_{2-}}$ $\mathrm{O}_{7}$, two layers of perovskite-type structure, $\mathrm{Sr}_{2} \mathrm{Ti}_{2} \mathrm{O}_{6}$ is separated by one SrO-layer.

Protonic conduction in non-perovskite-type oxides have been investigated and some doped pyrochlore-type oxides such as $\mathrm{Ln}_{2} \mathrm{Zr}_{2} \mathrm{O}_{7}(\mathrm{Ln}=\mathrm{La}, \mathrm{Nd}, \mathrm{Gd}$ and $\mathrm{Sm})$ were also found to be protonic conductor under hydrogencontaining atmosphere at elevated temperature when $\mathrm{Y}$ was partially substituted for $\mathrm{Zr}^{20\rangle}$ The conductivities of typical samples in hydrogen atmosphere are shown in Fig. 2. Ca-doped $\mathrm{La}_{2} \mathrm{Zr}_{2} \mathrm{O}_{7}$ ceramics were also reported to absorb relatively large amount of water vapor and to exhibit protonic conduction. ${ }^{21)}$

Furthermore, fluroite-type oxide based on $\mathrm{La}_{6} \mathrm{WO}_{12},{ }^{22}$ aragonite-type oxide based on $\mathrm{LaBO}_{3}{ }^{22}$ and some phosphates such as $\mathrm{LaPO}_{4}{ }^{23)}$ and $\mathrm{Ba}_{3}\left(\mathrm{PO}_{4}\right)_{2}{ }^{4)}$ were confirmed to have protonic conduction under hydrogen-containing atmosphere at elevated temperature although their conductivities were generally low compared to those of the perovskites.

In Table 1, typical examples of high temperature-type proton conducting oxides and their distinct features are listed classifying them as their crystal structure. It has been still unclear what is essential for good protonic conduction in this class of oxides. However, empirical re-

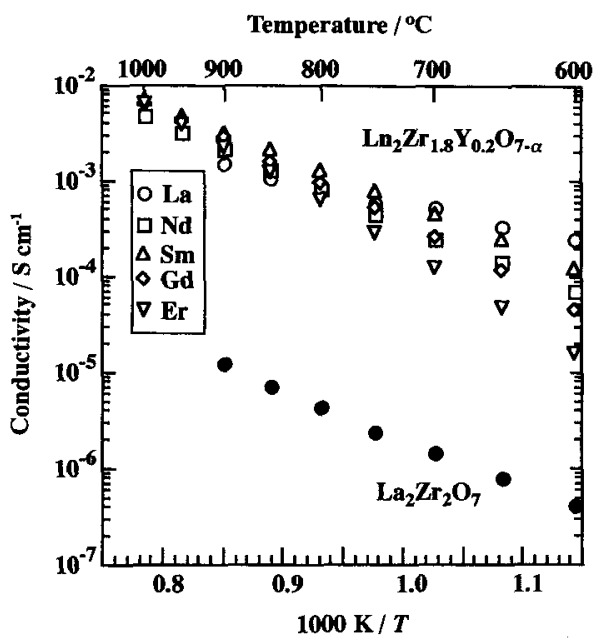

Fig. 2 Conductivities of proton conducting pyrochlore-type oxides, $\operatorname{Ln}_{2} \mathrm{Zr}_{1.8} \mathrm{Y}_{0.2} \mathrm{O}_{7-a}$ under hydrogen gas atmosphere.

Table 1 Typical examples of host oxides which exhibit protonic conduction under hydrogen-containing atmosphere at elevated temperatures.

\begin{tabular}{|l|l|l|}
\hline \multicolumn{1}{|c|}{ Crystal type } & \multicolumn{1}{|c|}{$\mathrm{Host}^{2}$ oxide } & \multicolumn{1}{c|}{ Feature } \\
\hline Single perovskite & $\mathrm{SrCeO}_{3}$ & High proton transport number \\
\cline { 2 - 3 } & $\mathrm{BaCeO}_{3}$ & $\begin{array}{l}\text { High conductivity } \\
\text { Mixed ionic conduction } \\
\left(\mathrm{H}^{+}+\mathrm{O}^{2-}\right)\end{array}$ \\
\cline { 2 - 4 } & $\begin{array}{l}\mathrm{SrZrO}_{3} \\
\mathrm{CaZrO}\end{array}$ & $\begin{array}{l}\text { Chemically stable } \\
\text { Mechanically strong } \\
\text { Low conductivity }\end{array}$ \\
\hline Mixed perovskite & $\begin{array}{l}\mathrm{Sr}_{2}\left(\mathrm{ScNb}_{3} \mathrm{O}_{6}\right. \\
\mathrm{Ba}_{3} \mathrm{CaNb}_{2} \mathrm{O}_{9}\end{array}$ & $\begin{array}{l}\text { High conductivity } \\
\text { Low stability in reducing } \\
\text { atmosphere at high temp. }\end{array}$ \\
\hline Layered perovskite & $\begin{array}{l}\mathrm{Sr}_{2} \mathrm{TiO}_{4} \\
\mathrm{Sr}_{3} \mathrm{Ti}_{2} \mathrm{O}_{7}\end{array}$ & $\begin{array}{l}\text { Proton-electron mixed cond. } \\
\text { over wide range of } P\left(\mathrm{H}_{2}\right)\end{array}$ \\
\hline Pyrochlore & $\begin{array}{l}\mathrm{Ln}_{2} \mathrm{Zr}_{2} \mathrm{O}_{7} \\
\left(\mathrm{Ln}_{2} \mathrm{La}_{2}, \mathrm{Sm} . . .\right)\end{array}$ & $\begin{array}{l}\text { Good stability } \\
\text { Low conductivity }\end{array}$ \\
\hline Fluorite & $\mathrm{La}_{6} \mathrm{WO}_{12}$ & \\
\hline Aragonite & $\mathrm{LaBO}_{3}$ & Low conductivity \\
\hline
\end{tabular}

quirements for good protonic conductors of this type seem to be ; 1) high basicity of constituent cation in the oxides, 2) partial substitution of aliovatent cations (dopants) for host cations or slight shift of composition from stoichiometric one, and 3) relatively high content of oxygen per chemical formula.

\section{Verification of Protonic Conduction}

Protonic conduction in these materials was verified directly by means of electrochemical permeation of hydrogen across the oxides. When one side of the ceramic specimen diaphragm attached with porous electrode was exposed to hydrogen gas and direct current was sent to it as schematically shown in Fig. 3, hydrogen gas was observed to evolve at the cathode at the rate of Faraday's law. Typical example is represented in Fig. 4 for $\mathrm{SrCe}_{0.95}$ $\mathrm{Yb}_{0.05} \mathrm{O}_{3-a}$ ceramic. ${ }^{25)}$ This indicates that the ceramic in hydrogen atmosphere is almost a pure protonic conductor.

Protonic conduction in the above specimen is also sup- 


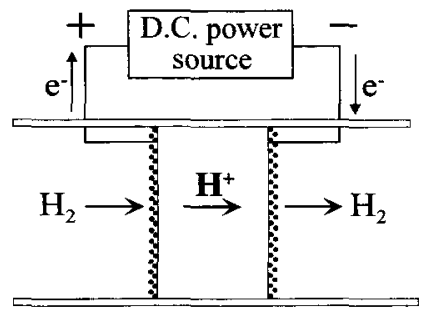

Fig. 3 Electrochemical permeation of hydrogen across a proton conducting oxide.

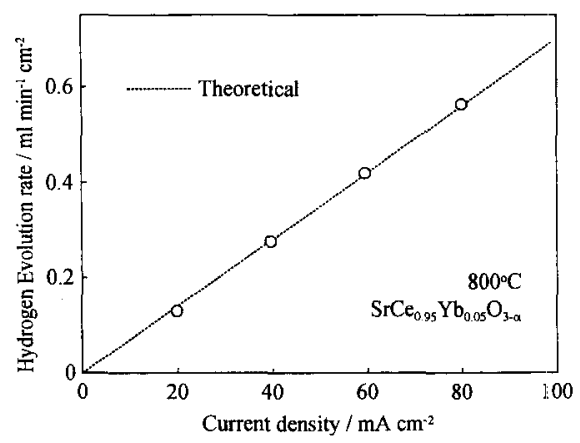

Fig. 4 Hydrogen evolution rate at the cathode of electrochemical gas cell using $\mathrm{SrCe}_{0.95} \mathrm{Yb}_{0.05} \mathrm{O}_{3-a}$ ceramic as an electrolyte. (Dotted line shows theoretical value)

ported by EMF behavior of hydrogen gas concentration cell using the specimen as a solid electrolyte. When hydrogen gases with different partial pressures were introduced to each electrode compartment of the cell at elevated temperatures, stable and reproducible EMF was observed. As shown in Fig. 5, the measured EMFs obey Nernst's equation given as

$$
E=\frac{R T}{2 F} \ln \frac{P\left(\mathrm{H}_{2}\right)(\mathrm{I})}{P\left(\mathrm{H}_{2}\right)(\mathrm{II})}
$$

where $P\left(\mathrm{H}_{2}\right)$ (I) and $P\left(\mathrm{H}_{2}\right)$ (II) are partial pressure of hydrogen in each compartment, and $R, F$ and $T$ have their usual meanings. This result indicates that the conduction under this condition is purely ionic. Similar behaviors were observed in the pyrochlore-type oxides above described.

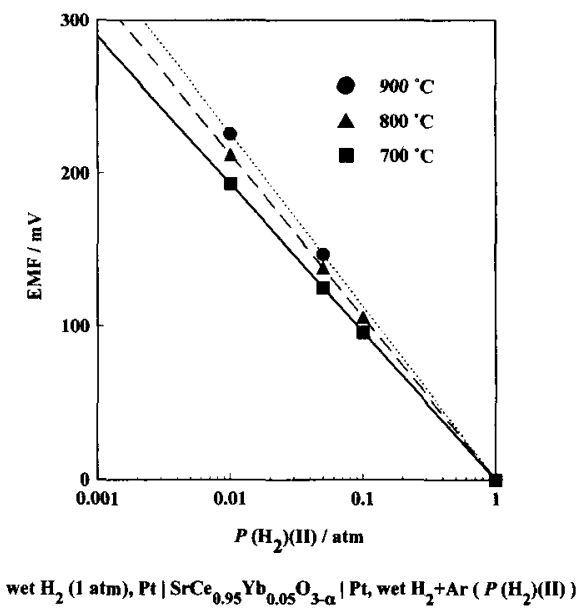

Fig. 5 EMF of hydrogen concentration cell using $\mathrm{SrCe}_{0.95-}$ $\mathrm{Yb}_{0.05} \mathrm{O}_{3-a}$ ceramic as an electrolyte. (Lines show theoretical values at each temperature)
Also, when steam was supplied to the anode compartment in the above cell and direct current was passed through the ceramic electrolyte, hydrogen gas was observed to evolve at the cathode compartment. ${ }^{1,2)}$ This is a kind of steam electrolysis, the principle of which is shown in Fig. 6. This means that the oxide ceramic behaves as a protonic conductor not only in the presence of hydrogen but also in the presence of water vapor at high temperature.

Protonic conduction in the presence of water vapor is also supported by EMF behavior of gas concentration cell using the specimen as a solid electrolyte. When dry oxygen gases of different partial pressures $(e . g$. dry air and dry pure oxygen at $1 \mathrm{~atm}$ ) are introduced to each electrode compartment of the cell, only a very small and unstable EMF is observed, indicating that the conduction in the oxide is mainly electronic. The electronic conduction in this case is p-type (hole conduction) since the conductivity of the specimen oxide in dry gas increases with increasing partial pressure of oxygen.

However, when air with different humidity is supplied to each electrode compartment, stable EMF is observed. In this case, the polarity of the electrode with higher humidity is negative. This is a kind of steam concentration cell, the EMF of which appears only when the conduction in the solid electrolyte is protonic. ${ }^{26)}$ The principle of the steam concentration cell is shown in Fig. 7. In the case of oxide-ionic conductor like stabilized zirconia, EMF can not be generated, in principle, in such a steam concentration cell. Table 2 shows the comparison of EMFs observed in gas cells using an oxide-ion conductor and a proton conductor as the solid electrolytes. ${ }^{26)}$ To check the generation of EMF of steam concentration cell using specimen diaphragm as a solid electrolyte is one of the easiest methods of screening test for searching for proton conducting solids at elevated temperatures.

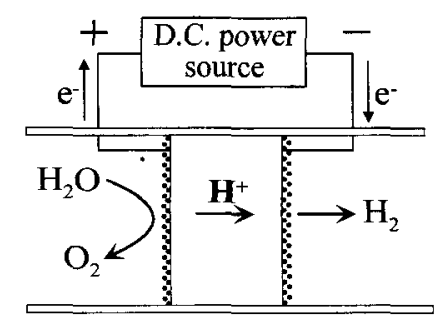

Fig. 6 Principle of steam electrolysis using a proton conductor.

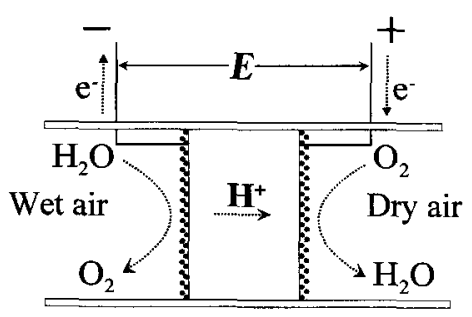

Fig. 7 Principle of steam concentration cell using a proton conductor. 
Table 2 EMF of various gas cells at $800^{\circ} \mathrm{C}$.

\begin{tabular}{|c|c|c|c|}
\hline \multirow{3}{*}{$\begin{array}{l}\text { Cell } \\
\text { No. }\end{array}$} & \multirow{3}{*}{$\begin{array}{c}\text { Cell type } \\
\text { Gas I / Gas II }\end{array}$} & \multicolumn{2}{|c|}{$\mathrm{EMF}(\mathrm{mV})^{\mathrm{b})}$} \\
\hline & & \multicolumn{2}{|c|}{ Electrolyte } \\
\hline & & $\begin{array}{c}\mathrm{O}^{2-} \text { conductor } \\
10 \mathrm{~m} / \mathrm{o} \mathrm{YSZ}\end{array}$ & $\begin{array}{c}\mathrm{H}^{+} \text {conductor } \\
\mathrm{SrCe}_{0.95} \mathrm{Yb}_{0.05} \mathrm{O}_{3-\alpha}\end{array}$ \\
\hline 1 & dry air / dry air & 0.6 & 0.0 \\
\hline 2 & wet air / dry air & 0.6 & $26.0\left(t_{\mathrm{H}+}=0.34\right)$ \\
\hline 3 & wet $\mathrm{N}_{2} /$ dry $\mathrm{N}_{2}{ }^{())}$ & 0.9 & $58.0\left(t_{\mathrm{H}^{+}}=0.74\right)$ \\
\hline 4 & dry $\mathrm{H}_{2} /$ dry $\mathrm{H}_{2}$ & 6.5 & 0.0 \\
\hline 5 & wet $\mathrm{H}_{2} /$ dry $\mathrm{H}_{2}$ & -56.5 & 0.0 \\
\hline 6 & dry air $/$ dry $\mathrm{O}_{2}$ & 36.2 & 2.0 \\
\hline 7 & wet air / dry $\mathrm{O}_{2}$ & 36.4 & $14.0\left(t_{\mathrm{H}^{+}}=0.39\right)$ \\
\hline 8 & wet air / wet $\mathrm{O}_{2}$ & 36.4 & 30.5 \\
\hline
\end{tabular}

a) Wet gas : saturated with $\mathrm{H}_{2} \mathrm{O}$ at room temperature $\left(P\left(\mathrm{H}_{2} \mathrm{O}\right)=\right.$ 19.8 Torr for cell 5, 23.8 Torr for cell 2 and 3) ; dry gas : saturated with $\mathrm{H}_{2} \mathrm{O}$ at $0{ }^{\circ} \mathrm{C}\left(P\left(\mathrm{H}_{2} \mathrm{O}\right)=4.58\right.$ Torr $)$.

b) Negative sign shows that the electrode of gas II is negative.

c) Partial pressure of oxygen in $\mathrm{N}_{2}$ gas is $3 \times 10^{-1} \mathrm{~atm}$.

\section{Defect Equilibria for Proton Insertion}

These oxides are unique solid electrolytes in respect to the fact that they have no host constituents which liberate conducting ions (protons). The oxides take protons from water vapor or hydrogen molecules in ambient gas as a result of equilibria with defects in the oxide lattice at elevated temperatures. In these oxides, doping by aliovalent cations is indispensable for the appearance of protonic conduction. It seems that electron-holes and oxygen vacancies formed by doping might play an important role in the formation of protons. For example, substitution of $\mathrm{Yb}^{3+}$ for $\mathrm{Ce}^{4+}$ in $\mathrm{SrCeO}_{3}$ will provide oxygen vacancies $\mathrm{V}_{0}{ }^{\circ}$ as a result of charge compensation in the stoichiometric condition

$$
\mathrm{Yb} \longrightarrow \mathrm{Yb}_{\mathrm{ce}}{ }^{\prime}+1 / 2 \mathrm{~V}_{\mathrm{o}}{ }^{\cdot}
$$

and the oxygen vacancies are in equilibrium with surrounding atmosphere at elevated temperatures as described below.

The studies on the electrical conductivity as a function of the dopant content or partial pressures of water vapor and oxygen showed that the following three equilibria are simultaneously established between the defects in the oxide and the atmosphere. ${ }^{27,28)}$

$$
\begin{aligned}
& \mathrm{V}_{0} \cdot+1 / 2 \mathrm{O}_{2} \stackrel{K_{1}}{\rightleftarrows} \mathrm{O}_{0}{ }^{x}+2 \mathrm{~h} . \\
& \mathrm{H}_{2} \mathrm{O}+2 \mathrm{~h}^{\cdot \stackrel{K_{2}}{\rightleftarrows}} 2 \mathrm{H}^{\cdot}+1 / 2 \mathrm{O}_{2}
\end{aligned}
$$

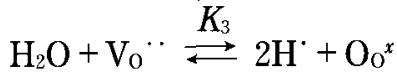

where, $\mathrm{V}_{0}{ }^{*}, \mathrm{O}_{0}{ }^{x}, \mathrm{H}^{*}, \mathrm{~h}^{*}$ and $K$ represent oxygen vacancy, oxide-ion at normal lattice site, proton, hole and equilibrium constant, respectively, and the relationship between the equilibrium constant of each equation is expressed as

$$
K_{3}=K_{1} K_{2} .
$$

These equilibria could be qualitatively confirmed by experiments. For example, the sintered oxide of $\mathrm{SrCe}_{0.95-}$ $\mathrm{Yb}_{0.05} \mathrm{O}_{3-a}$ was observed to liberates or absorbs water vapor when the partial pressure of oxygen $P\left(\mathrm{O}_{2}\right)$ in the ambient atmosphere was suddenly raised or reduced, respectively. ${ }^{28}$ These phenomena can be understood from Eq.(4). As the partial pressure of oxygen increases, the equilibrium of Eq.(4) shifts to the left hand side liberating the water vapor into the atmosphere and vice versa. Inversely, when the partial pressure of water vapor $P\left(\mathrm{H}_{2} \mathrm{O}\right)$ is raised abruptly, the sintered oxide liberates oxygen to the atmosphere, and it absorbs oxygen when the water vapor pressure is reduced as shown in Fig. $8{ }^{28)}$ This experiment has been done in a flow of argon gas at $800^{\circ} \mathrm{C}$ by breaking ample in which $\mathrm{CuSO}_{4} \cdot 5 \mathrm{H}_{2} \mathrm{O}$ was sealed up and by measuring the change in water vapor pressure and oxygen partial pressure at the exit gas. The phenomena shown in Fig. 8 can also be explained by Eq.(4).

Large-scale thermogravimetric analysis also showed the validity of the above equilibria. ${ }^{29,30)}$ Figure 9 represents the change in weight of $\mathrm{SrCe}_{0.95} \mathrm{Yb}_{0.05} \mathrm{O}_{3-a}$ on changing the partial pressure of oxygen at $1000^{\circ} \mathrm{C}$ keeping the $P\left(\mathrm{H}_{2} \mathrm{O}\right)$ constant. ${ }^{29)}$ Obviously, the weight increased on lowering the partial pressure of oxygen and vice versa. This means that the oxide absorbs or desorbs the water
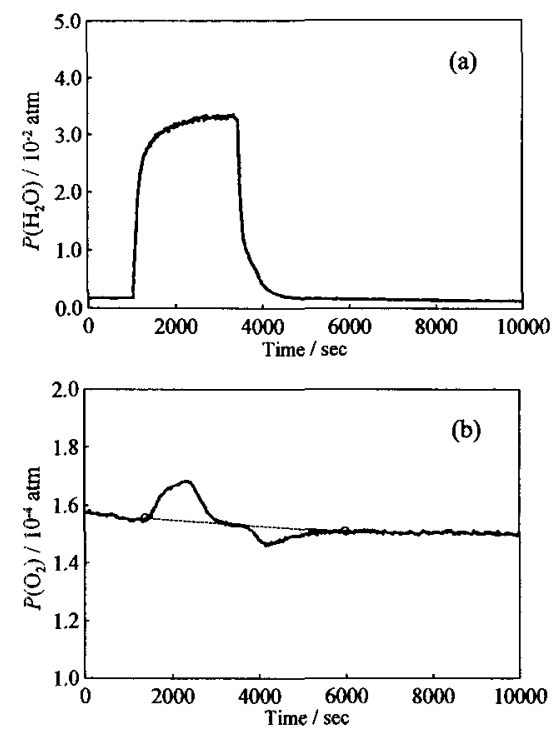

Fig. 8 Change in oxygen partial pressure on pulse injection of water vapor into argon gas flow (flow rate $: 30 \mathrm{ml} \mathrm{min}^{-1}$ ) by heating $\mathrm{CuSO}_{4} \cdot 5 \mathrm{H}_{2} \mathrm{O}:$ (Specimen $: \mathrm{SrCe}_{0.95} \mathrm{Yb}_{0.05} \mathrm{O}_{3-a}$, $\left.600^{\circ} \mathrm{C}\right)$

(a) Change in water vapor pressure by heating $\mathrm{CuSO}_{4} \cdot 5 \mathrm{H}_{2} \mathrm{O}$.

(b) Change in oxygen partial pressure in response to change of $P\left(\mathrm{H}_{2} \mathrm{O}\right)$ in (a).

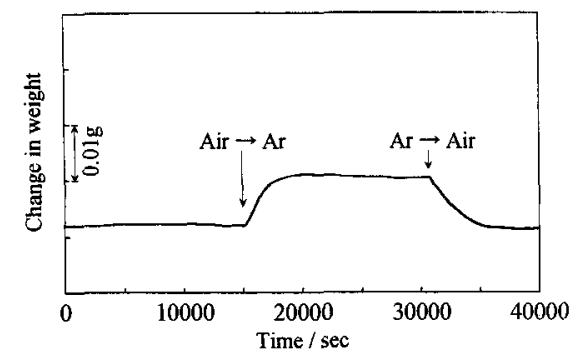

Fig. 9 Change in weight of $\mathrm{SrCe}_{0.95} \mathrm{Yb}_{0.05} \mathrm{O}_{3-a}$ on changing the partial pressure of oxygen in the atmosphere at $1000^{\circ} \mathrm{C}$. $P\left(\mathrm{H}_{2} \mathrm{O}\right)=1.21 \times 10^{-2} \mathrm{~atm}$., Sample weight $=80.4078 \mathrm{~g}$. 
vapor and that Eq.(5) shifts toward the right hand side when Eq.(3) shifts to the left and vice versa.

The solubility of water vapor or hydrogen has been studied by several groups reporting comparable values. $^{28-34)}$ Figure 10 shows an example in which the proton content in $\mathrm{SrCe}_{0.95} \mathrm{Yb}_{0.05} \mathrm{O}_{3-a}$ under wet air was determined from the solubility of water vapor measured as a function of temperature and a content of dopant. ${ }^{30)}$ The content decreases from $0.03 \sim 0.045$ proton/unit formula of $\mathrm{SrCeO}_{3}$ at $600^{\circ} \mathrm{C}$ to less than 0.01 at $1000^{\circ} \mathrm{C}$. It is clear from this figure that the content of proton in non-doped oxide is very low, indicating that the doping by aliovalent cations is indispensable for formation of protons in the oxides.

A protonated oxide of this kind shows some broad IR absorption bands due to $\mathrm{OH}$ stretching, indicating the existence of a somewhat weak $\mathrm{OH}$ bond in the oxide $^{36-38)}$ These bands shift toward small wave number on substituting $\mathrm{D}$ for $\mathrm{H}$ and, accordingly, the conductivity decreases. According to the neutron diffraction study of Sc-doped $\mathrm{SrTiO}_{3}$ by Sata et al . ${ }^{38)}$ there exist two equivalent sites for proton between adjacent oxygens in the perovskite-type oxide, one of which can be occupied by the proton as illustrated in Fig. 11.

These results suggest hopping and rotating mechanism of proton or deuteron changing $\mathrm{OH}$ - (or OD-) bond one after another as schematically shown in Fig. 12. According to Ishigame and his coworkers, this mechanism was supported by physical phenomena observed in the experiments on a quasi-elastic photo scattering and a

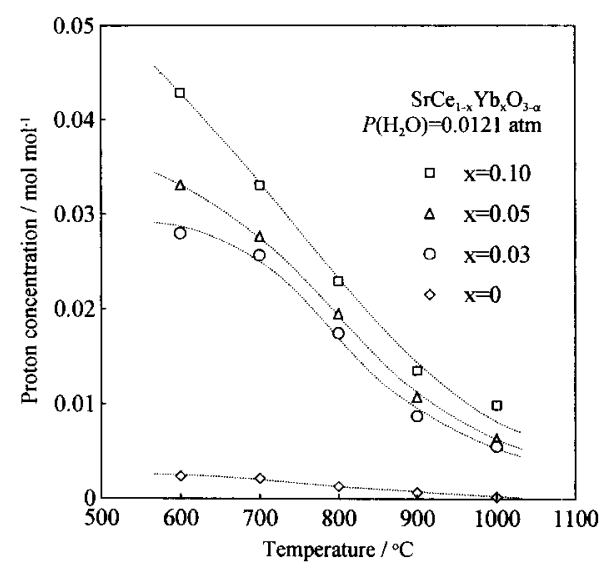

Fig. 10 Proton concentration in $\mathrm{SrCe}_{1-x} \mathrm{Y}_{x} \mathrm{O}_{3-a}$.

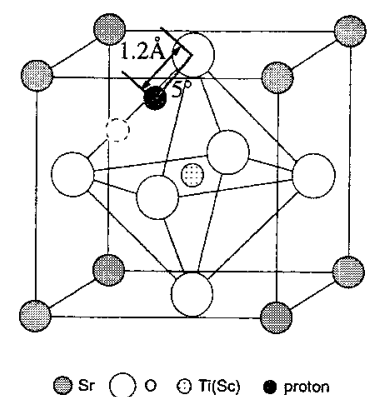

Fig. 11 The average position of proton in $\mathrm{SrTi}_{0.98} \mathrm{Sc}_{0.02} \mathrm{O}_{3}$ decided by neutron diffraction. After Sata et al. (Ref. 38) (Dotted circle indicates another available position between two oxygens).

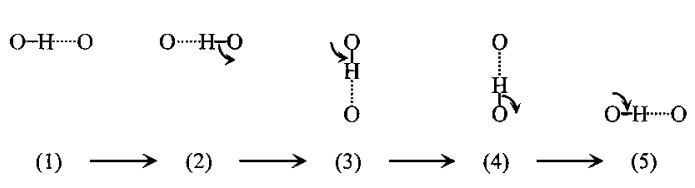

Fig. 12 Proton migration in perovskite-type oxide. (The figures indicate the sequence of migration and rotation)

hole burning method. ${ }^{39-41)}$ The energy required for proton movement in the oxide and their isotope effect were discussed in detail by Kreuer et al ${ }^{42}$

Microscopic mechanism of the proton diffusion in Ydoped $\mathrm{SrCeO}_{3}$ has been studied by Shimojo et al . using a first-principles molecular-dynamics simulation. ${ }^{43}$ ) They reported that the proton formed an $\mathrm{O}-\mathrm{H}$ bond with the neighboring oxide-ion and that the frequency of the $\mathrm{O}-\mathrm{H}$ stretching vibration depended on the position of the proton in this oxide crystal. The frequencies obtained by their simulations were consistent with the experimental results obtained from the infrared-transmission spectra. They observed two types of diffusion paths ; one was diffusion around the oxide-ion while retaining the $\mathrm{O}-\mathrm{H}$ bond, and the other was diffusion between the two neighboring oxide-ions while switching the $\mathrm{O}-\mathrm{H}$ bond. Similar quantum molecular dynamics study of proton diffusion in perovskite-type oxides was also reported. ${ }^{44)}$

\section{Possible Applications}

Proton conducting ceramics, usable at elevated temperatures, have distinctive advantages in applications compared to those of low temperature type. They can be used in situ at high temperature, for example, as a hydrogen sensor for high temperature industrial processes. High temperature protonic conductors are applicable not only for sensors but also for electrolyzers, galvanic cells for power supply, etc., which need high electrolytic current. For those devices, high temperature is advantageous since electrode reactions take place more smoothly than at low temperatures. In other words, high temperature makes the polarization small and enables high efficiency operation.

Possible applications of high temperature proton conducting solid electrolytes are listed in Table 3 classifying by functions of an electromotive force and a protonpreferential permeation. Technological challenges in the application of proton conducting ceramics developed by the authors have been reviewed in the previous papers. ${ }^{45-47)}$ Those are briefly summarized in the following together with very recent achievements.

\section{1 Hydrogen sensors}

Galvanic-cell-type hydrogen sensors, steam sensors and hydrocarbon sensors usable at high temperature can be fabricated ${ }^{48)}$ They are essentially based on the principle of the hydrogen concentration cell using a proton conducting solid electrolyte. For measurements of hydrogen activity in fused aluminum in the casting process, this type of hydrogen sensor has been commercialized by a Japanese company using a $\mathrm{CaZr}_{0.9} \mathrm{In}_{0.1} \mathrm{O}_{3-a}$ ceramic. ${ }^{49)}$ This sensor may also be applied for other fused metal like zinc or copper. ${ }^{50)}$ 
Table 3 Possible applications of high temperature proton conducting solid electrolytes.

\begin{tabular}{|l|l|l|}
\hline \multicolumn{1}{|c|}{ Function } & $\begin{array}{l}\text { Phenomena } \\
\text { applicable }\end{array}$ & \multicolumn{1}{|c|}{ Application } \\
\hline EMF & Signal & $\begin{array}{l}\text { Hydrogen gas sensor } \\
\text { Steam sensor } \\
\text { Hydrocarbons sensor } \\
\text { Hydrogen sensor for molten metals } \\
\mathrm{H}^{+}-\mathrm{D}^{+} \text {isotope sensor } \\
\text { Fuel cell }\end{array}$ \\
\hline \multirow{2}{*}{$\begin{array}{l}\text { Electrochem. } \\
\text { permeation } \\
\text { of hydrogen }\end{array}$} & Peparation & $\begin{array}{l}\text { Hydrogen extractor } \\
\text { Hydrogen pump } \\
\text { Regulator of hydrogen gas pressure } \\
\text { Isotope concentrator }\end{array}$ \\
\cline { 2 - 3 } & Electrolysis & $\begin{array}{l}\text { Steam electrolyzer for hydrogen production } \\
\text { Dehumidifier } \\
\mathrm{H}_{2} \mathrm{~S} \text { electrolyzer for desulphuration } \\
\text { HCl electrolyzer for } \mathrm{Cl}_{2} \text { recovery }\end{array}$ \\
\cline { 2 - 3 } & Reaction & $\begin{array}{l}\text { Hydrogenation of organic compounds } \\
\text { Dehydrogenation of organic compounds }\end{array}$ \\
\cline { 2 - 3 } & & \\
\hline
\end{tabular}

\section{2 Fuel cells}

The use of a protonic conductor as a solid electrolyte for fuel cell has distinctive features compared with that of the oxide ion conductor. As illustrated in Fig. 13, when a protonic conductor is used instead of oxide ion conductor, fuel circulation is unnecessary in the case of hydrogen fuel cell because no water molecules are generated at the fuel electrode. Furthermore, in the case of hydrocarbon fuel cell, only thermally produced hydrogen is consumed as a fuel, and residual parts can be brought out as the useful reformed products $(e . g$. ethylene from ethane).

A laboratory-scale hydrogen fuel cell using $\mathrm{SrCe}_{0.95^{-}}$ $\mathrm{Yb}_{0.05} \mathrm{O}_{3-a}$ ceramic as an electrolyte diaphragm worked stably at $800 \sim 1000^{\circ} \mathrm{C} .{ }^{51\rangle}$ When this cell was discharged, it generated water vapor at the cathode at the theoretical rate calculated from Faraday's law, indicating that the conduction in the electrolyte was protonic. ${ }^{52)}$ The fuel cells using $\mathrm{BaCeO}_{3}$-based ceramics generated much higher power than those using $\mathrm{SrCeO}_{3}$-based ceramics. $^{2,10,53)}$ However, they generated water vapor at both
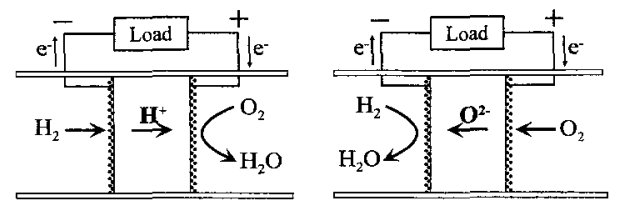

(a) Hydrogen fuel cells
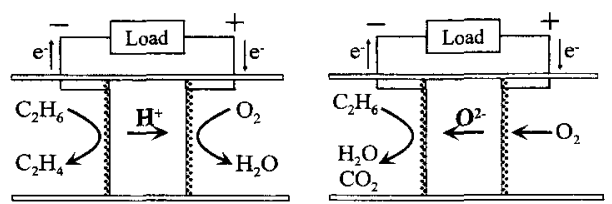

(b) Ethane fuel cells

Fig. 13 Comparison of protonic conductor with oxide-ionic conductor in the case of hydrogen-fueled and ethane-fueled cells. electrodes suggesting that the conduction in the electrolyte was both protonic and oxide-ionic.

\section{3 Steam electrolysis and its derivatives}

When a hydrogen fuel cell is operated inversely, water vapor at the anode is decomposed to form protons, which migrate to the cathode, where they discharge to produce hydrogen as shown in Fig. 6. This can be a kind of steam electrolyzer for hydrogen production. A benchscale steam electrolyzer was fabricated using one end closed ceramic tubes made of $\mathrm{SrCe}_{0.95} \mathrm{Yb}_{0.05} \mathrm{O}_{3-a}$ a as a solid electrolyte. The electrolyzer worked stably at $750^{\circ} \mathrm{C}$, and pure and very dry hydrogen (dew point $<-30^{\circ} \mathrm{C}$ ) could be extracted at the rate of $3 \mathrm{l} / \mathrm{h}^{{ }^{45,54)}}$

If oxygen is supplied to the cathode of this cell, protons which have migrated from the anode react with oxygen to form water vapor. Outwardly, this cell can be regarded as a steam pump and this type of cell was also confirmed to work stably. ${ }^{55}$ It is also possible to construct an electrochemical dehumidifier based on the principle of steam electrolysis or the steam pump using a proton conducting solid electrolyte. It was verified that the dehumidifier using a $\mathrm{SrCeO}_{3}$-based proton conducting ceramic worked successfully in laboratory-scale experiments and that the dehumidifier could desiccate down to $0.67 \mathrm{~Pa}$ (dew point ; about $-45^{\circ} \mathrm{C}$ ) This kind of device has a possibility as a convenient dehumidifier that can be equipped to small scientific instruments. ${ }^{56)}$

\section{4 Hydrogen pump}

Since only protons can be transported in these oxides, electrochemical hydrogen separation from various gas mixtures is possible. ${ }^{57}$ This is a kind of hydrogen pump. Hydrogen extraction experiments from thermal cracking gas of ethane $e^{54)}$ and hydrogen sulfide ${ }^{583}$ at $800^{\circ} \mathrm{C}$ have been demonstrated using a thin disk of $\mathrm{SrCe}_{0.95} \mathrm{Yb}_{0.05} \mathrm{O}_{3-a}$ ceramic as a solid electrolyte diaphragm. Hydrogen could be extracted from mixed gas of hydrogen and hydrocarbons using $\mathrm{BaCe}_{0.9} \mathrm{Nd}_{0.1} \mathrm{O}_{3-\alpha}$ as an electrolyte at $650^{\circ} \mathrm{C} .{ }^{99}$ )

Combining the function of electrochemical hydrogen pump with that of hydrogen sensing, the partial pressure of hydrogen in gases can be controlled. An example of the hydrogen regulation is shown in Fig. 14. The partial pressure of hydrogen in the inlet gas is analyzed by hydrogen sensor and a direct current corresponding to the difference between measured and desired hydrogen partial pressure is passed. The hydrogen partial pressure in the outlet gas from the pumping electrode was reanalyzed and the deviation from the desired value is fed back to pumping current supplier to regulate the pressure correctly. It was confirmed that this method could effectively control the partial pressure of hydrogen in gases with changeable hydrogen contents and flowrates. ${ }^{60)}$

\section{5 Membrane reactors}

A proton conducting ceramic membrane can be used, in principle, as a novel chemical reactor for hydrogenation or dehydrogenation of organic compounds. ${ }^{61)}$ In the hydrogenation, hydrogen can be brought directly to the reaction sites without contacting the reactant or product. In the dehydrogenation, separation procedure of the products from hydrogen is unnecessary. Dehydrogena- 

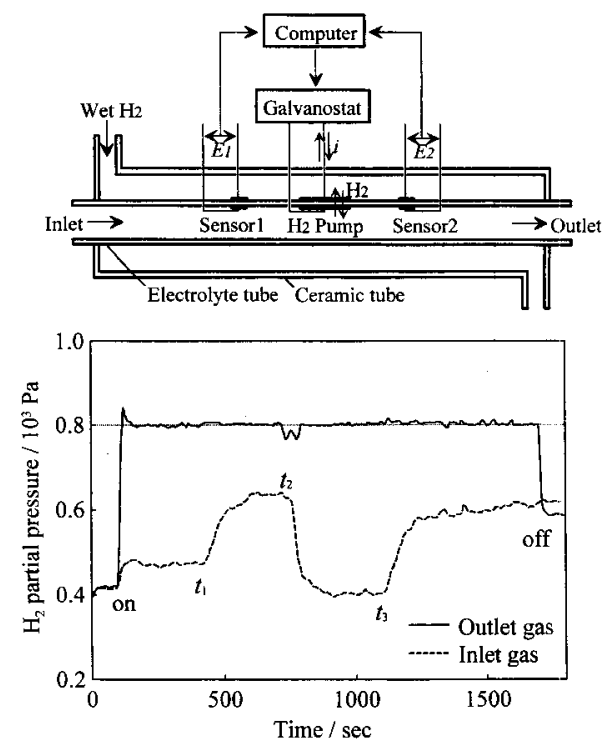

Fig. 14 Structure and performance of hydrogen partial pressure regulator.

tion of ethane has been tried with this method and confirmed to produce ethylene. ${ }^{62)}$ Dehydrogenative coupling of methane to obtain $\mathrm{C}_{2}$-compounds has been studied and observed to enhance the formation of ethane and ethylene on sending electric current to the cell. ${ }^{63,64)}$ The problems to be solved are to improve the yield of the product desired and to decrease electric loss for electrochemical reactors.

\section{6 Hydrogen isotope cells}

In the proton conducting electrochemical cell, the behavior of deuterium somewhat differs from that of usual hydrogen, due to the large difference in their mass. ${ }^{65}$ This affects both the migration of ions in the electrolyte and the electrode reactions, and marked isotope effect in the electrochemical reaction can be observed. ${ }^{66)}$ This phenomenon may be applied to concentrate heavy hydrogen.

Recently, a new concept of an electrochemical hydrogen isotope cell has been established in our laboratory. ${ }^{67.68)}$ The structure of this cell is similar to normal hydrogen gas concentration cell using a proton(hydrogen ion)-conducting solid electrolyte like $\mathrm{CaZr}_{0.9} \mathrm{In}_{0.1} \mathrm{O}_{3-a}$. If normal (light) hydrogen gas is introduced to one electrode compartment and heavy hydrogen gas to another, the cell gives rise to steady and reproducible EMF as shown in Fig. 15. In this case the polarity of the electrode for heavy hydrogen was positive. The EMF could be explained by the two factors ; the difference in mobilities of proton and deuteron in the electrolyte and the difference in electrode reactions of $\mathrm{H}_{2}$ and $\mathrm{D}_{2}$ gases. This phenomenon might be utilized to analyze the concentration of isotope in $\mathrm{H}_{2}-\mathrm{D}_{2}$ mixture since EMF depends linearly on $\mathrm{D}_{z}$-concentration when the mixture was used instead of pure $D_{2}$ in the above cell. ${ }^{69}$ ?

\section{Summary}

Starting with $\mathrm{SrCeO}_{3}$-based ceramics, some perovskitetype oxides and perovskite-related oxides have been proved to exhibit protonic conduction under hydrogen-
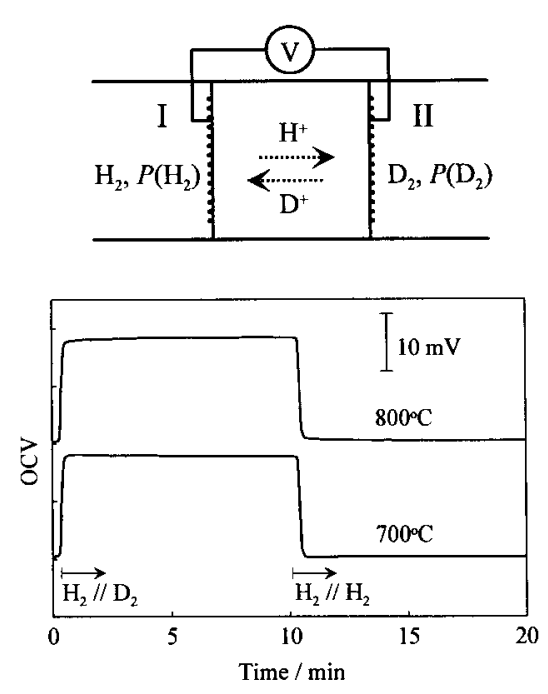

Fig. 15 EMF response of $\mathrm{H}_{2}-\mathrm{D}_{2}$ cell. Electrolyte : $\mathrm{CaZr} 0.9-$ $\mathrm{In}_{0.1} \mathrm{O}_{3-a}$.

containing atmosphere at elevated temperatures. In addition, non-perovskite-type oxides such as some of pyrochlore-type and fluorite-type oxides have become clear to behave as a protonic conductor like the perovskites. Their electrochemical properties and defect equilibria with surrounding atmosphere were discussed. Possibilities of electrochemical devices using the proton conducting ceramics were outlined and some of them were verified to work satisfactorily in a laboratory scale.

\section{References}

1) H. Iwahara, T. Esaka, H. Uchida, and N. Maeda, Solid State Ionics, 3/4, 359 (1981).

2) H. Iwahara, H. Uchida, K. Ono, and K. Ogaki, J. Electrochem. Soc, 135, 529 (1988).

3) N. Bonanos, B. Ellis, and M. N. Mahmood, Solid State Ionics, 44, 305 (1991).

4) R. C. T. Slade and N. Shigh, Solid State Ionics, 61, 111 (1993).

5) W. Lee, A. S. Nowick, and L. A. Boaturmer, Solid State Ionics, 18/19, 989 (1986).

6) T. Norby and P. Kofstad, J. Am. Ceram. Soc., 67, 786 (1984).

7) T. Yajima, H. Kazeoka, T. Yogo, and H. Iwahara, Solid State Ionics, 47, 271 (1991).

8) H. Iwahara, T. Yajima, T. Hibino, K. Ozaki, and H. Suzuki, Solid State Ionics, 61, 65 (1993).

9) H. Fujii, K. Katayama, T. Shimura, and H. Iwahara, $J$. Electroceramics, 2, 199 (1998).

10) N. Tanigichi, K. Hatoh, J. Niikura, T. Gamo, and H. Iwahara, Solid State Ionics, 53-57, 998 (1992).

11) H. Iwahara, T. Yajima, T. Hibino, and H. Ushida, J. Electrochem. Soc., 140, 1687 (1993).

12) K. D. Kreuer, E. Schonherr, and J. Maier, Solid State Ionics, 70/71, 278 (1994).

13) H. Uchida, A. Yasuda, and H. Iwahara, Denki Kagaku (presently Electrochemistry), 57, 103 (1989).

14) T. Yajima, K. Koide, K. Yamamoto, and H. Iwahara, Proc. Third Int. Meeting on Chemical Sensors, Cleveland, p.303 (1990). 
15) T. Yajima, H. Suzuki, T. Yogo, and H. Iwahara, Solid State Ionics, 51, 101 (1992).

16) A. S. Nowick and Y. Du, Solid State Ionics, 77, 137 (1995).

17) T. Shimura, K. Suzuki, and H. Iwahara, Solid State Ionics, 104, 79 (1997).

18) T. Shimura, K. Suzuki, and H. Iwahara, Solid State Ionics, 125, 313 (1999).

19) T. Shimura, K. Suzuki, and H. Iwahara, Solid State lonics, 113, 355 (1998).

20) T. Shimura, M. Komori, and H. Iwahara, Solid State Ionics, 86, 685 (1996).

21) T. Omata, K. Okuda, S. Tsugimoto, and S. OtsukaMatuso-Yao, Solid State Ionics, 104, 249 (1997).

22) T. Shimura, S. Fujimoto, and H. Iwahara, in contribution to Solid State Ionics.

23) T. Norby and N. Christiansen, Solid State Ionics, 77, 240 (1995).

24) H. Iwahara, K. Warashina, T. Shimura, and H. Matsumoto, Proc. 3rd Int. Symp. on Ionic, and Mixed Conducting Ceramics, Paris (1997).

25) M. Balkanski, T. Takahashi, and H. L. Tuller Eds., Solid State Ionics, p. 575 Elsevier, Amsterdam (1992).

26) H. Iwahara, H. Uchida, and N. Maeda, Solid State Ionics, 11, 109 (1983).

27) H. Uchida, N. Maeda, and H. Iwahara, Solid State Ionics, 11, 117 (1983).

28) H. Uchida, H. Yoshikawa, and H. Iwahara, Solid State Ionics, 34, 103 (1989).

29) T. Yajima and H. Iwahara, Solid State Ionics, 50, 281 (1992).

30) T. Yajima and H. Iwahara, Solid State Ionics, 53-56, 983 (1992).

31) T. Ishigaki, S. Yamauchi, K. Kishio, K. Fueki, and H. Iwahara, Solid State Ionics, 21, 239 (1986).

32) H. Uchida, H. Yoshikawa, and H. Iwahara, Solid State Ionics, 35, 229 (1989).

33) F. Krug, T. Schober, R. Paul, and T. Springer, Solid State Ionics, 77, 185 (1995).

34) J. Eschenbaum, J. Rosenberger, R. Hempelmann, D. Nagen-gast, and A. Weidinger, Solid State Ionics, 77, 222 (1995).

35) H. H. Huang, M. Ishigame, and S. Shin, Solid State Ionics, 47, 251 (1991).

36) T. Hibino, K. Mizutani, T. Yajima, and H. Iwahara, Solid State Ionics, 58, 85 (1992).

37) H. Yugami, Y. Shibayama, T. Hattori, and M. Ishigame, Solid State Ionics, 79, 171 (1995).

38) N. Sata, K. Hiramoto, M. Ishigame, S. Hosoya, N. Niimura, and S. Shin, Phys. Rev. B 54, 15795 (1996).

39) H. Yugami, S. Matsuo, and M. Ishigame, Solid State Ionics, 77, 195 (1995).

40) H. Yugami, Y. Chiba, and M. Ishigame, Solid State Ionics, 77, 201 (1995).

41) N. Sata, H. Matsuta, Y. Akiyama, Y. Chiba, M. Ishigame, and S. Shin, Solid State Ionics, 97, 437 (1997).

42) K. D. Kreuer, A. Fuchs, and J. Maier, Solid State Ionics,
77, 157 (1995).

43) F. Shimojo, K. Hoshino, and H. Okazaki, J. Phys. Soc. Jpn., 67, 2008 (1998).

44) W. Munch, K-D. Kreuer, G. Seifetli, and J. Maier, Solid State Ionics, 125, 39 (1999).

45) H. Iwahara, Solid State Ionics, 77, 289 (1995).

46) H. Iwahara, Solid State Ionics, 86, 9 (1996).

47) H. Iwahara, Proc. 17th Risoe Int. Symp. on Material Science Denmark, p. 13 (1996).

48) H. Iwahara, Solid State Ionic Materials, (Eds. B. V. R. Chowdari, M. Yahaya, I. A. Talib, and M. M. Salleh) World Scientific, Singapore, p.79 (1994).

49) T. Yajima, K. Koide, N. Fukatu, T. Ohashi, and H. Iwahara, Sensors, and Actuators, B 13-14, 697 (1993).

50) N. Fukatsu, N. Kurita, K. Koide, and T. Ohashi, Solid State Ionics, 113, 219 (1998).

51) H. Iwahara, H. Uchida, and N. Maeda, J. Power Sources, 7, 293 (1.982).

52) H. Iwahara, H. Uchida, and N. Maeda, Solid State Ionics, 9, 1021 (1983).

53) N. Bonanos, K. S. Knight, and B. Ellis, Solid State Ionics, 79, 161 (1995).

54) H. Iwahara, T. Esaka, H. Uchida, T. Yamauchi, and K. Ogaki, Solid State Ionics, 18/19, 1003 (1986).

55) H. Iwahara, T. Hibino, and T. Sunano, J. Appl. Electrochem., 26, 829 (1996).

56) H. Iwahara, H. Matsumoto, and K. Takeuchi, To be published in Solid State Ionics.

57) H. Iwahara, Solid State Ionics, 125, 271 (1999).

58) H. Iwahara, E. Yasumoto, T. Esaka, and H. Uchida, Denki Kagaku (presently Electrochemistry), 59, 76 (1991).

59) E. Yasumoto, T. Esaka, and H. Iwahara, Denki Kagaku (presently Electrochemistry), 61, 247 (1993).

60) H. Matsumoto, T. Suzuki, and H. Iwahara, Solid State Ionics, 116, 99 (1999).

61) H. Iwahara, Solid State Ionics ; Materials, and Applications, (Eds. B.V.R. Chowdari, S. Chandra, S. Singh, and P. C. Srivastava) World Scientific, Singapore, p. 247 (1992).

62) S. Hamakawa, T. Hibino, and H. Iwahara, J. Electrochem. Soc., 141, 1720 (1994).

63) P. H. Chiang, D. Eng, and M. Stoukides, Solid State Ionics, 61, 99 (1993).

64) S. Hamakawa, T. Hibino, and H. Iwahara, J. Electrochem. Soc., 140, 459 (1993).

65) T. Sherban and A. S. Nowick, Solid State Ionics, 35, 189 (1989).

66) T. Hibino, K. Mizutani, and H. Iwahara, J. Electrochem. Soc., 140, 2588 (1993).

67) H. Matsumoto, K. Takeuchi, and H. Iwahara, J. Electrochem. Soc., 146, 1486 (1999).

68) H. Matsumoto K. Takeuchi, and H. Iwahara, Solid State Ionics, 125, 377 (1999).

69) H. Matsumoto and H. Iwahara, To be published in Solid State Ionics. 